\title{
An Investigation into the Impact of Mobile Technologies on Economic Growth and Employment in the Caribbean
}

\author{
By Lloyd Amaghionyeodiwe* \\ Fenio Annansingh-Jamieson ${ }^{\dagger}$
}

\begin{abstract}
The adoption of mobile technologies in developing countries in Africa, the Caribbean and Asia has grown exponentially. People in poor regions are using mobile phones for banking, business transactions, socializing, staying connected and monitor the weather. This has reduced the need for travel, lead to the creation of new businesses, shorten supply chains and boost productivity. Consequently, these technologies can be used to eliminate the time and distance barriers between businesses and their customers. This paper examined the impact of mobile technologies in ten Caribbean countries which are primarily developing countries. It utilized a cross-country panel data and regression analysis to estimate and investigates the impact of mobile technologies on economic growth. Results from the paper showed that all the coefficient of the mobile technology components namely the internet user ratio, mobile-cellular telephone subscriptions and the fixed-telephone subscriptions were all significant and positive across all the regressions. This is because of the belief that they contribute to the knowledge spillover, which consequently enhances economic growth.
\end{abstract}

Keywords: Mobile technology; Internet; Mobile Cellular; Fixed Telephone; Economic growth

\section{Introduction}

The technological environment in which businesses operate is not only dynamic but increasingly complex and challenging. Mobile technology (MT) including portable devices such as: laptop computers, palmtop computers or personal digital assistants, mobile phones and smart phones, global positioning system (GPS) devices, wireless debit/credit card payment terminals (Perry et al., 2001 and Nah et al., 2005) have extended computing and the Internet into the wireless medium, and provides greater flexibility in communication, collaboration, and knowledge sharing. The exponential nature of technological change, characterized by perceived increases in the benefits associated with these technologies provide businesses with opportunities for growth, increased productivity, reduced cost, faster response to customers, amongst others.

\footnotetext{
${ }^{*}$ Department of Accounting and Finance, School of Business and Information Systems, York college, USA.

${ }^{\dagger}$ Department of Business and Economics, School of Business and Information Systems, York college, USA.
} 
Hence, MT plays a key role in society, impacting gross domestic product (GDP), productivity, and employment. This is evident from the level of investment and loans provided by leading financial institutions, among others. Precisely, mobile technology enhances economic growth through a multifactor productivity gain. It aids business enterprises in improving productivity by facilitating the adoption of more efficient business processes (e.g., marketing, inventory optimization, and streamlining of supply chains). And also accelerates innovation by introducing new consumer applications and services (e.g., new forms of commerce and financial intermediation).

According to Chu (2013), internet (as a mobile technology) may help to fight against economic downturn as it positively impacts the economy by spreading information, stimulating innovation, building up network, fostering business, and deepening capital, improving labor market, strengthening market competition, and helping firms to profit from emerging markets. Furthermore, in line with Harris (1998), MT can help facilitates access to information and reduces search costs while firms adopting the internet are able to communicate better, faster and at lower costs thereby reducing internal as well as external transaction costs and thus lowering production costs and enhance productivity which helps generate economic growth.

From the above, it is evident that MT offers an incentive, motivates and stimulates economic growth in an economy. Accordingly, it is the premise of this study is, that with the wide-spread use of MT, markets will be more efficient as risk and uncertainty are reduced. MT allows for greater market integration and penetration, increased productivity, reduced price fluctuations and increased price dispersion. This inevitably will impact on the economic performance of a country, in terms of productivity, employment and ultimately the GDP. Thus, this paper utilizes data from secondary sources like the World Bank, United Nations and the International Telecommunication Union (ITU) for selected Caribbean countries from 1996 to 2013, to investigate the effect of MT on economic growth proxied by the GDP. Closely following this introductory section is Section two which reviews the literature while section three contains the methodology and empirical analysis including the discussions on the study's result. Section four concludes the study.

\section{Literature Review and Theoretical Framework}

\section{Literature Review}

As MT becomes cheaper, more people have access to mobile devices than they do clean drinking water or electricity in some countries. In a remarkably short period of time, mobile technology has become an important part of everyday life for some in the emerging and developing world. The internet, in particular has been key in connecting the people who otherwise would have depended on third parties to conduct transactions. People are using their mobile technologies for a variety of purposes, especially for texting and taking 
pictures, while smaller numbers also use their phones to get political, consumer and health information. In the developed nations, the popularity of these technologies is quite high for example, Pew Research Centre (2015) found that $85 \%$ of American adults own a mobile phone and nearly two-thirds own a smartphone. Also, $10 \%$ of Americans who own a cell phone does not have broadband at home.

These technologies have also gained significance and popularity in businesses (Andersen et al., 2003). Examples of this can be seen in the increased accessibility and connectivity of mobile devices to corporate Intranet (Nah et al., 2005), M-brokerage services (Looney et al., 2004), M-commerce and banking (Mallat et al., 2004 and Herzberg, 2003) increase sale owing to mretail (Hume, 2014), and electronic procurement (Gebauer and Shaw, 2004). With such a huge user acceptance rate, mobile technologies are transforming remote farms, rural health centers, water supplies, governance, democracy, businesses, job markets and the way world's poorest people live. This can be seen for example, in Niger, where access to mobile phones has allowed grain traders to compare market prices across the country, decreasing travel cost and resulting in increased profit of nearly 30 percent for traders. In Rwanda, where mobile phones are allowing micro-entrepreneurs to develop new business contacts and enhance customer service (Donner, 2007), improve the quality of life for fishermen in Kerala, India (Abraham, 2007). In Kenya, rural AIDS patients receive text messages, reminding them to take their antiretroviral drugs. A recent UNESCO study claimed that hundreds of thousands of people in developing countries are using their mobile phones to read, thus suggesting that mobile technology could help tackle illiteracy and boost access to educational and reading materials. In countries such as Ethiopia, Ghana, India, Kenya, Nigeria, Pakistan and Zimbabwe where books can be scarcer than cell phones, this becomes a cheaper way to access books and stories. From the survey, 62 percent of respondents were reading more as a result of mobile reading. More than $10 \%$ of respondents said their primary reason for reading on their phone was because it was more affordable while another $9 \%$ said it was because they don't otherwise have access to books or stories.

Therefore, these technologies are reshaping the way individuals see and access the world. The rate of IT adoption is becoming increasingly important to business longevity in the twenty-first century; indeed, 62 per cent of small businesses are in the process of becoming online businesses, with a further 29 per cent recognizing the need to do so (Dearne, 2001). Further, more than nine in ten ( 95 per cent) medium-sized businesses are now connected to the Internet (Dearne, 2001). Several explanations can be given for this user uptake in developing countries such as the low cost, substitution effects due to the poor performance of the fixed telecommunications network, long waiting lists for fixed line connections and better customer care services by mobile telecommunications operators (Grube, 2001). The relationship between competition and user acceptance is particularly interesting as there are increasing number of firms who are offering these technologies which leads to faster diffusion of innovations 
The main advantage of mobile technology is mobility, which supports anytime, anywhere access by removing time and distance barriers in accessing critical information and enhancing capabilities for communication, coordination, collaboration, customer service and knowledge sharing (Sheng et al., 2005). Hence users can have access to the Internet, corporate intranet, and mobile applications instantaneously. Therefore, MT can result in increased efficiency, effectiveness and productivity as users are able to better utilize their time and attend to business and social obligations. Thus, lessening information irregularities in markets and making rural and undeveloped markets more efficient (Sarker and Wells, 2003). Hence, MT plays a key role in society, impacting GDP, productivity, and employment. This is evident from the level of investment and loans provided by the world's leading financial institutions concerned with the alleviation of poverty, development and economic growth. For example, in 2011, nearly 75 percent of all World Bank investment lending projects had an Information and Communication Technology (ICT) component, and more than \$4 billion was invested in the ICT sector between 2003 and 2010. Owing to this stimulus, user acceptance of MT in developing countries has been exponential, since of the 6 billion mobile subscriptions worldwide almost 5 billion are from developing countries.

Chu (2013) study investigated the impact of the internet on economic growth and this impact during the recession using data from World Bank in a panel of 201 countries from 1988 to 2010. He used the OLS model and his findings reveal that a 10-percentage point increase in internet penetration rate raises real GDP per capita by 0.57 to 0.63 percentage points. Also, during the recession relative to expansion, the coefficient of internet reduces but it still remains statistically positive. Thus, he concluded that the internet provides a way to solve the problem of economic recession and contributes significantly to the GDP.

The International Telecommunication Union (ITU) (2012) and (2014) report on the impact of broadband on the economy affirmed that the research on the contribution of broadband to GDP growth has confirmed its positive impact. Some studies in this regard include Thompson and Garbacz (2008) whose study was on 46 US States during the period 2001-2005 and they found that a $10 \%$ increase in broadband penetration is associated with $3.6 \%$ increase in efficiency. Czernich et al. (2009) study were on twenty-five (25) Organisation for Economic Co-operation and Development (OECD) countries for the period 1996 and 2007. They found that a 10\% increase in broadband penetration raises per- capita GDP growth by 0.9 to $1.5 \%$ points. Qiang et al. (2009) study were in two parts: The first part was done for sixty-six (66) selected high-income countries for the period 1980 to 2002 and they found that $10 \%$ increase in broadband penetration yielded an additional 1.21 percentage points of GDP growth. While the second part was from 1980 to 2002 for one hundred and twenty (120) selected low and middle-income countries. They also found that a $10 \%$ increase in broadband penetration yielded an additional 1.38 in GDP growth. Farhadi, Ismail, and Fooladi (2012) examined the impact of Information and Communication Technology (ICT) use on economic 
growth. Their study utilized panel data for 159 countries over the period 2000 to 2009. They found a positive relationship between the growth rate of real GDP per capita and ICT use index (as measured by the number of internet users, fixed broadband internet subscribers and the number of mobile subscription per 100 inhabitants). Furthermore, they found that the effect of ICT use on economic growth is higher in high-income group rather than other groups implying that if these countries seek to enhance their economic growth, they need to implement specific policies that facilitate ICT use.

In all, it can be opined from the various studies that MT has a positive contribution to the GDP growth both for developed and developing countries and regions.

\section{Theoretical Framework}

The endogenous growth theory place greater importance on the need for governments to actively encourage technological innovation. It argued that in the free market classical view, firms may have no incentive to invest in new technologies because they will struggle to benefit in competitive markets. Lucas (1988), and Romer (1990) are among the proponents of the endogenous growth theory in economic literature. The premise of this theory is that endogenous growth is caused by accumulating technology (or knowledge) and they thus established a link between the level of human capital and economic growth. In the Romer model, new knowledge enters into the production process in three ways. First, a new design is used in the intermediate goods sector for the production of a new intermediate input. Second, in the final sector, labor, human capital, and available producer durables produce the final product. Third, and a new design increases the total stock of knowledge which increases the productivity of human capital employed in the research sector.

Technology is not explicitly incorporated, even as both neo-classical and new growth theorists agree that total factor productivity TFP represents the best measure of technology change and exercises a dominant influence on a country's growth performance. According to Domar (1961), and Hulten (2001), TFP can be interpreted as a measure of the rate of disembodied technological change, as long as the firm is on its production frontier, there are constant returns to scale and markets are competitive. More generally, TFP is a combination of effects arising from the scale of operations and increasing returns to scale, technical efficiency, technological change, plus measurement error (Coelli et al., 2005, Diewert and Nakamura 2007, Carlaw and Lipsey 2003). Technological progress in the ICT sector has a positive impact on aggregate TFP, whose size depends crucially on the relative size of the ICT industry (Biagi, 2013).

One of the main points of the endogenous growth model is that the rate of technological progress should not be taken as a constant in a growth model government policies can permanently raise a country's growth rate if they lead to more intense competition in markets and help to stimulate product and process innovation. There are increasing returns to scale from new capital 
investment. The model emphasized that innovations are a crucial driver for technological development of production process. Since IT is a generalpurpose platform technology for leveraging innovations (Bresnahan and Trajtenberg, 1995; Helpman, 1998; Varian et al., 2004), it can enhance technological development of production process and lead to an increase in TFP. But according to Mačiulytè-Šniukienè and Gaile-Sarkane (2014), It is not easy to evaluate cause-effect and impact of technological, economic and social development in order to prove that ICT are the factor of economic increase of efficiency, productivity and growth. Nevertheless, it can be presumed the huge progress in the field of ICT is the main cause of economic changes of both commercial companies and the economy as a whole, and these changes, are expressed by the growth of labor productivity. ICT frees productive resources to expand the overall output of an economy to the extent that it raises productivity of the existing capital stock and of labour, MačiulytèŠniukienè and Gaile-Sarkane (2014).

There are five cause-effect chains of how ICT impacts economic growth ${ }^{1}$. These are:

- Cause-effect chain 1: ICT development $\rightarrow$ implementation of organizational novelties and management reorganization $\rightarrow$ effectiveness and productivity growth $\rightarrow$ economic growth.

- Cause-effect chain 2: ICT development $\rightarrow$ more efficient mechanism of distribution of market transactions and market $\rightarrow$ effectiveness and productivity growth $\rightarrow$ economic growth.

- Cause-effect chain 3: ICT development $\rightarrow$ growth possibilities of income, depending on operational scale $\rightarrow$ new and improved final products $\rightarrow$ economic growth.

- Cause-effect chain 4: ICT development $\rightarrow$ social and cultural changed within a society $\rightarrow$ effectiveness and productivity growth $\rightarrow$ economic growth.

- Cause-effect chain 5: ICT development $\rightarrow$ development possibilities of education and knowledge management innovations $\rightarrow$ strengthening of innovative processes $\rightarrow$ economic growth $\rightarrow$ progress in ICT development

Katz (2009) noted that ICT has been found to have a direct influence on the economy at four levels: Productivity; Creation/relocation of enterprises; Employment, Economic growth. Furthermore, he stated that research on the economic impact of telecommunications technology confirms the findings at the ICT aggregate level. For example, telecommunications networks have been found to have an impact at five levels namely: Tele-commuting: improvement in quality of life resulting from ability to work remotely; Labor productivity: greater efficiency in processing of information-related tasks; Transaction speed: faster completion of inter-firm transactions, with consequent reduction

\footnotetext{
${ }^{1}$ See Серикова (2003) as cited by Mačiulytè-Šniukienè and Gaile-Sarkane (2014).
} 
of costs; Innovation capacity: innovation can be increased by streamlined collaboration among eco-system firms; And modular and flexible production processes: standardized optimized processes can only be achieved through flexible reconfiguration and simplification.

From the above, this study hypothesis is that mobile technology, being part of information technology has a positive contribution in enhancing economic growth.

\section{Methodology and Empirical Result}

\section{The Model and Data}

\section{$\underline{\text { The Model }}$}

The role of technology in enhancing economic growth is well entrenched in economic literature. According to Romer's $(1986,1990)$ knowledge spillover plays a positively significant role in ensuring a balanced growth as was submitted in the endogenous growth model. In the endogenous growth model as propounded by Barro's (1998) highlights the role of knowledge and innovation in promoting economic growth. Many studies have confirmed this and among them is Choi and Yi, (2009), who using cross-country panel data, showed evidence that the internet plays a positive and significant role in disseminating knowledge and consequently in economic growth. Based on these studies and the models used, we adopted an econometric model with economic growth, proxied by the GDP as a function of labor, human capital proxied by secondary education enrolment and technology, which includes the number of individuals using the internet, mobile-cellular telephone subscriptions, and fixed-telephone subscriptions.

Thus, the model for the study was specified as:

Growth $_{i t}=\beta_{0}+\beta_{1}$ Labor $_{i t}+\beta_{2}$ Human Capital $_{i t}+\beta_{3}$ Internet $_{i t}+\beta_{4}$ Mobilecellular Telephone $_{i t}+\beta_{5}$ Fixed-telephone $_{i t}+u_{i t}$

Where $u_{i t}=\eta_{i}+v_{t}+\varepsilon_{i t}$,

- $\quad \eta_{i}$ is an individual (country) effect, and $v_{t}$ is a time effect, and $\varepsilon_{i t}$ is independently and identically distributed among countries and years.

- Growth $_{i t}$ is the real per-capita GDP growth rate of country $i$ at year $t$;

- Labor $_{i t}$ is the labor force participation rate

- Human capital $_{i t}$ is secondary education enrolment;

- Internet is the ratio of the Internet users to total population

- Mobile-cellular Telephone $_{i t}$ is the mobile-cellular telephone subscriptions

- Fixed-telephone ${ }_{i t}$ is the fixed-telephone subscriptions 
Estimation Technique

The Generalized Method of Moments (GMM) estimator was used for the study. This is an estimation procedure that allows economic models to be specified while avoiding often unwanted or unnecessary assumptions, such as specifying a particular distribution for the errors. This lack of structure means GMM is widely applicable, although this generality comes at the cost of a number of issues, the most important of which is questionable small sample performance. Generalized Method of Moments (GMM) extends the classical setup in two important ways. The first is to formally treat the problem of having two or more moment conditions which have information about unknown parameters. GMM allows estimation and inference in systems of Q equations with $\mathrm{P}$ unknowns, $\mathrm{P} \leq \mathrm{Q}$. The second important generalization of GMM is that quantities other than sample moments can be used to estimate the parameters. GMM exploits laws of large numbers and central limit theorems to establish regularity conditions for many different "moment conditions" that may or may not actually be moments. These two changes produce a class of estimators that is broadly applicable.

Various methods have been used to access the role of information technology in economic growth but in recent times, the Moments (GMM) have been prevalent. Pesaran and Smith (1995) and Im, Pesaran and Shin (2002) showed that the ordinary least squares (OLS) approach can yield highly misleading outcomes resulting from the problems of serial correlation between regressors and error terms which the conventional OLS fails to detect when working with dynamic panel relationships. As a way out, economists recommended the use of instrumental variables, panel data techniques such as Pooled Mean Group (PMG) (Pesaran, Shin, and Smith (1999)) and Generalized Method of Moments (GMM) procedure of Arellano and Bond (1991). And according to Roodman (2006), GMM estimator is advantageous for panel data with a relatively small-time dimension, as compared to the number of cross sections as is the case in this paper. Based on this, the GMM method first proposed by Holtz-Eakin, Newey, and Rosen (1988) appears to be appropriate for our estimation. In the estimation, lags of the dependent and independent variables are used as instruments and the dynamic panel data model is then applied to the complete panel dataset.

$\underline{\text { Data }}$

The study was based on data collected for the following selected Caribbean countries: Antigua and Barbuda, Bahamas, Barbados, Cuba, Dominica, Dominican Republic, Grenada, Jamaica, St. Kitts and Nevis, St. Lucia, St. Vincent and the Grenadines and Trinidad and Tobago. The data was collected from secondary sources which include International Telecommunication Union (ITU) (2012 and 2014), International Monetary Fund (IMF), World Bank (2012 and 2014), World Bank Global ICT Department (2014), United Nations Educational, Scientific and Cultural 
Organization (UNESCO) (2014), United Nations (UN) (2014), additional data was obtained from reports and publications in some of the selected countries. The data covers the period 1996 to 2013 so as to reflect when most of the countries got more involved in the use of the internet and other mobile technology. The summary statistics of the data is provided in Table 1 below.

Table 1. Summary Statistics of the Data

\begin{tabular}{|c|c|c|c|c|c|c|}
\hline Variables & GDP & $\begin{array}{c}\text { Internet } \\
\text { Use }\end{array}$ & $\begin{array}{c}\text { Mobile } \\
\text { Cellular }\end{array}$ & $\begin{array}{c}\text { Fixed } \\
\text { Telephone }\end{array}$ & $\begin{array}{c}\text { Human } \\
\text { Capital }\end{array}$ & Labor \\
\hline Mean & 10.1536 & 29.08258 & 43.41926 & 3.515207 & -18.461 & -13.2066 \\
\hline Standard Error & 3.088801 & 4.28214 & 5.699012 & 1.073407 & 2.442168 & 2.027987 \\
\hline Median & 6.48084 & 15.5668 & 23.24571 & 4.536661 & -0.82935 & 0.101195 \\
\hline $\begin{array}{c}\text { Standard } \\
\text { Deviation }\end{array}$ & 62.99943 & 62.93435 & 91.53968 & 21.52174 & 40.57234 & 37.17362 \\
\hline $\begin{array}{c}\text { Sample } \\
\text { Variance }\end{array}$ & 3968.928 & 3960.733 & 8379.514 & 463.1855 & 1646.115 & 1381.878 \\
\hline Kurtosis & 248.561 & 6.19361 & 14.88245 & 16.23844 & 0.376664 & 1.653317 \\
\hline Range & 1232.961 & 472.286 & 691.6789 & 226.4094 & 174.2826 & 174.2826 \\
\hline Minimum & 99.9234 & 100 & 100 & 100 & 100 & 100 \\
\hline Maximum & 1133.037 & 372.286 & 591.6789 & 126.4094 & 74.28261 & 74.28261 \\
\hline Count & 844 & 844 & 844 & 844 & 844 & 844 \\
\hline $\begin{array}{c}\text { Confidence } \\
\text { Level (95.0\%) }\end{array}$ & 6.071646 & 8.440352 & 11.22271 & 2.110208 & 4.80772 & 3.989194 \\
\hline
\end{tabular}

Note: The growth rates of the data were used for the study

\section{Empirical Result}

Though our focus was on using the GMM estimator, we included some other methods in our estimation of the growth equation (1). These methods include pooled ordinary least squares (OLS); individual random effects; individual fixed effects; time fixed effects; individual random effects and time fixed effects; and generalized method of moments (GMM) estimation. This was also in line with Choi and Yi, (2009), which was adapted and modified for our study. The regression result is contained in Table 2. The table shows the results from the various estimations of the growth equation. In line with our expectation, and starting with the pooled OLS regression, the coefficient the telecommunication variables were positive and significant. For instance, the coefficient of internet-user ratio was positive and significant at $1 \%$ level. And given its coefficient of 3.812 , it implies that a $1 \%$ increase in the internet-user ratio will lead to an increase in growth rate by $0.038 \%$. For, the mobile technology and fixed telephone, they were both positive and significant at $5 \%$ level, an indication that when they increase, the growth rate also increases. The coefficient of labor was positive and significant but that of human capital was positive but not significant. This tends to show that though human capital has a positive relationship with the economic growth but it was not a significant factor in enhancing growth. One possible reason for this might be the level of human capital development in these countries which tend not to be 
encouraging. As can be seen from the table, labor had a contrasting effect in that it was positive and significant at $5 \%$ level, indicating that an increase in when labor increases by $1 \%$, growth also increases by $0.018 \%$.

Table 2. Empirical Result from Data Estimation

\begin{tabular}{|c|c|c|c|c|c|c|}
\hline & $\begin{array}{l}(\mathbf{a})^{\mathrm{b}} \\
\text { Pooled } \\
\text { OLS }\end{array}$ & $\begin{array}{c}\text { (b) } \\
\text { Individua } \\
\text { I Random }\end{array}$ & $\begin{array}{c}\text { (c) } \\
\text { Individua } \\
\text { I Fixed }\end{array}$ & $\begin{array}{c}\text { (d) } \\
\text { Time } \\
\text { Fixed }\end{array}$ & $\begin{array}{c}\text { (e) } \\
\text { Individua } \\
\text { l Random } \\
\text { \& Time } \\
\text { Fixed }\end{array}$ & $\begin{array}{l}(\mathbf{f})^{\mathbf{b}, \mathbf{c}} \\
\text { Panel } \\
\text { GMM }\end{array}$ \\
\hline Constant & $\begin{array}{c}3.423 \\
(0.917)\end{array}$ & $\begin{array}{c}2.617 \\
(0.992)\end{array}$ & & & $\begin{array}{l}-1.081 \\
(-0.799)\end{array}$ & $\begin{array}{c}3.139 \\
(2.011)^{* *}\end{array}$ \\
\hline Internet & $\begin{array}{c}3.812 \\
(2.110)^{* *}\end{array}$ & $\begin{array}{c}4.693 \\
(1.974)^{* * *}\end{array}$ & $\begin{array}{c}2.813 \\
(2.170)^{* * * *}\end{array}$ & $\begin{array}{c}5.014 \\
(3.010)^{* *}\end{array}$ & $\begin{array}{c}4.909 \\
(2.211)^{* * *}\end{array}$ & $\begin{array}{c}6.143 \\
(2.934)\end{array}$ \\
\hline $\begin{array}{l}\text { Human } \\
\text { Capital }\end{array}$ & $\begin{array}{c}1.404 \\
(1.013)\end{array}$ & $\begin{array}{c}1.641 \\
(0.091)\end{array}$ & $\begin{array}{c}2.104 \\
(1.029)\end{array}$ & $\begin{array}{c}1.108 \\
(0.013)\end{array}$ & $\begin{array}{c}1.027 \\
(1.018)\end{array}$ & $\begin{array}{c}1.577 \\
(1.010)\end{array}$ \\
\hline Labor & $\begin{array}{c}1.887 \\
(2.003)^{* *}\end{array}$ & $\begin{array}{c}3.125 \\
(2.914)^{* * *}\end{array}$ & $\begin{array}{c}2.567 \\
(1.986)^{*}\end{array}$ & $\begin{array}{c}3.111 \\
(2.104)^{* *}\end{array}$ & $\begin{array}{c}1.974 \\
(1.605)\end{array}$ & $\begin{array}{c}1.421 \\
(0.976)\end{array}$ \\
\hline $\begin{array}{c}\text { Mobile } \\
\text { Cellular }\end{array}$ & $\begin{array}{c}2.886 \\
(2.976)^{* *}\end{array}$ & $\begin{array}{c}3.120 \\
(2.001)^{* *}\end{array}$ & $\begin{array}{c}4.152 \\
(2.963)^{* * * *}\end{array}$ & $\begin{array}{c}3.445 \\
(2.138)^{* *}\end{array}$ & $\begin{array}{c}2.915 \\
(2.002)^{* *}\end{array}$ & $\begin{array}{c}2.089 \\
(1.985)^{*}\end{array}$ \\
\hline $\begin{array}{c}\text { Fixed } \\
\text { Telephon } \\
\text { e } \\
\end{array}$ & $\begin{array}{c}2.712 \\
(1.103)\end{array}$ & $\begin{array}{c}3.165 \\
(2.103)^{* *}\end{array}$ & $\begin{array}{c}3.897 \\
(2.225)^{* * * *}\end{array}$ & $\begin{array}{c}3.171 \\
(2.114)^{* *}\end{array}$ & $\begin{array}{c}2.829 \\
(1.996)^{*}\end{array}$ & $\begin{array}{c}2.861 \\
(2.010)^{* *}\end{array}$ \\
\hline $\mathbf{R}^{2}$ & 0.47 & 0.63 & 0.64 & 0.53 & 0.68 & \\
\hline $\begin{array}{c}\mathrm{J}- \\
\text { Statistics } \\
\text { (P-Value) }\end{array}$ & & & & & & $\begin{array}{l}13.416 \\
(2.312)\end{array}$ \\
\hline $\begin{array}{c}\text { Sample } \\
\text { Size }\end{array}$ & 844 & 844 & 844 & 844 & 844 & 478 \\
\hline
\end{tabular}

Source: Computed from Regression result

Notes: a. $* * *, * *$, and, $*$ indicate significance at the $1 \%, 5 \%$, and, $10 \%$ levels, respectively. $\mathrm{T}$ - are in parentheses.

b. Newey and West's (1987) heteroscedasticity and autocorrelation consistent covariance matrix assuming a lag length of one was used.

c. Instrumental variables include constant, (Growth) $)_{t-2}, t-3$, (Internet Users) $)_{t-2}, t-3,(\text { Labor })_{t-2}, t-3$,

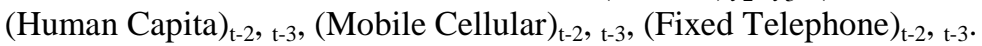

Similar to the study of Choi and Yi (2009), we re-estimated our growth model using panel data regression methods to help capture the individual random effects, individual fixed effects, time fixed and individual random effects and time fixed effects. The results are also contained in Table 2. The coefficients for the telecommunication variables were all significant for these effects though at varying level and coefficients. The internet-user ratio had an estimation coefficient that ranges from 2.813 to 5.014and it was positive and significant at $1 \%$ level except for the combined individual fixed effects and individual random effects and time fixed effects where it was significant at $5 \%$ 
level. An implication of this is that when there is $1 \%$ increase in the internet user ratio, the growth rate turned out to increase by between 0.028 and $0.051 \%$. For the mobile cellular usage ratio and the fixed telephone usage ratio, the results showed similar trends as they both have positive coefficient and were significant at varying level. The mobile cellular usage ratio was significant at $1 \%$ for the individual random effects, individual fixed effects, and time fixed effects but for a combined individual random effects and time fixed effects, it was significant at 5\% level. For labor, it was also positive and significant at 5\% level for the individual random and time fixed effects while for the individual fixed effect it was significant at $10 \%$. It was not significant for the combined individual random effects and time fixed effects. For the human capital variable, the result showed that the effects very positive but not significant except for the combined individual random effects and time fixed effects which had a negative co-efficient.

Furthermore, given that the explanatory variables such as the Internet, labor, human capital, mobile technology and fixed telephone usage can be influenced by economic growth, we carried out a Generalized Method of Moments (GMM) estimation to take into account any endogeneity of the explanatory variables. It has been argued that GMM is an estimation procedure that allows economic models to be specified while avoiding often unwanted or unnecessary assumptions, such as specifying a particular distribution for the errors and also mostly used when you have endogeneity between the dependent variables and want to instrument them with a lagged dependent variable. The result is also contained in Table 2 . The coefficients of internet user ratio, mobile technology and fixed telephone are all positive and significant. For internet user ratio, it was significant at $1 \%$ level, while for mobile technology and fixed telephone, it was significant at 5\% level. The coefficient of labor was positive but not significant while that of human capital was negative though not significant. And in line with Hansen and Singleton, (1982), the Hansen's JStatistic was 13.416 with a p-value of 2.312 , This suggests that the model was well specified.

In all, the coefficient of the internet user ratio, mobile-cellular telephone subscriptions and the fixed-telephone subscriptions were all significant and positive across all the regressions. This is because of the belief that they contribute to the knowledge spillover, which consequently enhances economic growth. 


\section{Conclusion}

This study investigated the impact of mobile technology on economic growth. This was based on the premise that mobile technology motivates and stimulates economic growth in an economy through greater market integration and penetration, increased productivity, reduced price fluctuations and increased price dispersion. We used various estimation techniques to examine this effect and these techniques are pooled ordinary least squares (OLS); individual random effects; individual fixed effects; time fixed effects; individual random effects and time fixed effects; and generalized method of moments (GMM) estimation. The estimation by the GMM helped us to obtain efficient estimators. The result showed mobile technology has a significant effect on the economic growth of the selected Caribbean countries. This was evident based on the coefficient measuring the effect of the mobile technology use on economic growth, which was both significant and positive. This implies that mobile technology can significantly enhance and promote economic growth of these countries in a positive way and thus the diffusion of the new technology has the tendency to fast-track the stride of economic growth, especially in the Caribbean region. Furthermore, the coefficient of the mobile technology, internet user ratio and the fixed-telephone subscriptions were all significant and positive implying that any increase in the use of information technology through increase in the number of internet users, fixed broadband internet subscribers and the number of mobile subscription have the tendency of enhancing and boosting their economic growth. Thus, the government in the region needs to intensify their efforts to further develop mobile technologies as a means of improving the region's economic growth. The government should encourage more ICT infrastructure, provide up-to-date structures and educate people in order to use these mobile technologies efficiently. This can subsequently lead to more internet users, fixed telephone and mobile technology usage and consequently increase real GDP per capita via network effects. Also, given that the coefficient of labor was positive though not significant and human capital was negative and not significant, the government need to promulgate policies that will enhance labor productivity and human capital development. This can be done through the use of information technology as such government should avoid policies that discourage use mobile technology, internet and fixed broadband internet subscribers like raising IT prices, raising barriers to Internet use, or prioritizing IT production at the expense of use. Policies that increase both secondary tertiary education and reduce telecommunications costs should be encouraged as these have the tendency of increasing the benefits derived from IT investment in the selected countries. 


\section{References}

Abraham R., (2007). "Mobile Phones and Economic Development: Evidence from the Fishing Industry in India". Information Technologies and International Development, 4, (1), pp.5-17.

Andersen, K.V., Fogeigren-Pedersen, A., Varshney U., (2003) "Mobile organizing using information technology (MOBIT)". Information Communication and Society, 6 (2), pp. 211-228.

Arellano M., Bond S. (1991) "Some tests of specification for panel data: Monte Carlo evidence and an application to employment equations". Review of Economic Studies 58: 277-297

Barro, R, J., (1998). "Determinants of Economic Growth: A Cross-Country Empirical Study", $1^{\text {st }}$ ed., The MIT Press, Cambridge.

Biagi, Federico (2013) "ICT and Productivity: A Review of the Literature". European Commission Joint Research Centre Institute for Prospective Technological Studies - Digital Economy Working Paper 2013/09. Http://ftp.jrc.es/EURdoc/ JRC84470.pdf

Bresnahan, T. and Trajtenberg, M., (1995) "General purpose technologies: engines of growth?" Journal of Econometrics, 65 (1), 83 - 108.

Carlaw K.I. and R.G. Lipsey (2003), "Productivity, technology and Economic Growth: What is the Relationship" in Journal of Economic Surveys, vol. 17 issue 3, pp. $457-495$.

Choi, C., Yi, and M. H., Yi (2009). "The Effect of the Internet on Economic Growth: Evidence from Cross-Country Panel Data". Economics Letters, 105(1): 39-41

Chu, Shan-Ying (2013) "Internet, Economic Growth and Recession". Modern Economy, 4, 209-213 http://dx.doi.org/10.4236/me.2013.43A023

Coelli T.J., Rao D.S.P., O'Donnel C.J. and Battese G.E. (2005), An Introduction to Efficiency and Productivity Analysis, 2nd edition, Springer.

Czernich, N., Falck, O., Kretschmer T., and Woessman, L. (2009). "Broadband infrastructure and economic growth". CESifo Working Paper No. 2861. December, Retrieved from www.ifo.de/DocCIDL/cesifo1_wp2861.pdf

Dearne, Karen (2001), "SMEs Learning the e-Ropes". The Australian, August, 41

Diewert W.E. and A. O. Nakamura (2007), "The Measurement of Productivity for Nations", in J.J. Heckman and E.E. Leamer (eds.) Handook of Econometrics, Elsevier, vol. 6, pp - 4501 - 4586

Domar E. D. (1961), "On the Measurement of Technological Change", The Economic Journal, 71: 709 - 729

Donner, J., (2007). "The Use of Mobile Phones by Micro-entrepreneurs in Kigali, Rwanda: Changes to Social and Business Networks". Information Technologies and International Development 3, (2) pp 3-19.

Farhadi, M., Ismail, R. and Fooladi, M. (2012) "Information and Communication Technology Use and Economic Growth”, PLoS ONE, Vol. 7, No. 11, http://dx. doi.org/10.1371/journal.pone.0048903

Gebauer, J. and Shaw M. J. (2004). "Success factors and impacts of mobile business applications: results from a mobile e-procurement study". International Journal of Electronic Commerce, 8 (3), pp. 19-41.

Grube, H. (2001), "Competition and innovation: The diffusion of mobile telecommunications in Central and Eastern Europe". Information Economics and Policy 13 (2001) 19-34

Hansen, L.P., (1982) "Large Sample Properties of Generalized Method of Moments Estimators". Econometrica 50, 1029-1054. 
Hansen, L.P. and K.J. Singleton, (1982) "Generalized Instrumental Variables Estimation of Nonlinear Rational Expectations Models". Econometrica 50, 1269-1286.

Harris, R.G. (1998) "The Internet as a GPT: Factor Market Implications". NBER Working Papers: 13886.

Helpman, E., (1998) "General Purpose Technologies and Economic Growth". MIT Press, Cambridge, MA.

Herzberg, A. (2003). "Payments and Banking with Mobile Personal Devices". Communications of the ACM, 46 (5), pp. 53-58.

Holtz-Eakin D., Newey W., and Rosen H.S. (1988) "Estimating Vector Autoregressions with Panel Data". Econometrica 56 (6) 1371-1395

Hulten, C.R. (2001) "Total Factor Productivity: A Short Biography”, in Hulten C. R., Dean E.R. and M. L. Harper (eds.) New Development in Productivity Analysis, National Bureau of Economic Research, Boston.

Im K.S., Pesaran M.H., and Shin Y. (2002) "Testing for unit roots in heterogeneous panels". Journal of Econometrics, 115 (1) 53-74

International Telecommunication Union (ITU) (2012) "The Impact of Broadband on the Economy: Research to Date and Policy Issues". Broadband Series, April.

International Telecommunication Union (ITU). (2014). Online statistics. From: http://www.itu.int/ITUD/ict/statistics/.

Katz, Raul L. (2009) "The Economic and Social Impact of Telecommunications Output: A Theoretical Framework and Empirical Evidence for Spain”. Intereconomics, 41-48, January/February. http://dx.doi.org/10.1007/s10272-009-0276-0

Looney, C.A., Jessup, L.M., and Valacich J.S. (2004). "Emerging business models for mobile brokerage services". Communications of the ACM, 47 (6), pp. 71-77.

Lucas, R. (1988) "On the Mechanics of Economic Development" Journal of Monetary Economics 22, 3-42

Mačiulytė-Šniukienė, Alma and Elina Gaile-Sarkane (2014) "Impact of information and telecommunication technologies development on labour productivity". Procedia - Social and Behavioral Sciences 110, 1271 - 1282.

Mallat, N. Rossi, M. and Tuunainen V.K (2004) "Mobile Banking Services". Communicates of the ACM, 47 (5) pp. 42-46.

Nah, F. Siau, K., and Sheng H. (2005). "The Value of Mobile Applications: A Study on a Public Utility Company". Communications of the ACM, 48 (2), pp. 85-90.

Newey, Whitney, and Kenneth West, (1987), "A Simple, Positive Semi-Definite, Heteroscedastic and Autocorrelation Consistent Covariance Matrix,". Econometric 55, 703-708.

Perry, M., O'hara, K., Sellen, A., Brown, B., and Harper, R. (2001). "Dealing with Mobility: Understanding Access Anytime, Anywhere". ACM Transaction on Computer-Human Interaction, 8 (4) pp. 323-347.

Pesaran M.H., Smith R. (1995) "Estimating long-run relationships from dynamic heterogeneous panels". Journal of Econometrics 68: 79-113

Pesaran M.H., Shin Y., and Smith R. (1999) "Pooled mean group estimation of dynamic heterogeneous panels". Journal of the American Statistical Association 94 (446) 621-34

Qiang, C. Z., and Rossotto, C. M. (2009). Economic Impacts of Broadband. In: "Information and Communications for Development 2009: Extending Reach and Increasing Impact", 35-50. Washington, DC: World Bank.

Rayman, N. (2014) "Cell Phones Could Help Millions in Developing Countries to Read”. Retrieved from: http://time.com/74584/unesco-study-mobile-phones-book -reading-literacy/ 
Romer, P. M., (1986). "Increasing Returns and Long-Run Growth". Journal of Political Economy, 94(5): 1002-37.

Romer, P. M., (1990). "Endogenous Technological Change". Journal of Political Economy, 98(5): 71-102.

Roodman, D. (2006) "How to do Xtabond2: An Introduction to Difference and System GMM in Stata", Working Paper No. 103, Center for Global Development, Washington DC, USA.

Samimi, A. J., R. B. Ledary, and M. H. J. Samimi (2015) "ICT and Economic Growth: A Comparison between Developed and Developing Countries". International Journal of Life Science and Engineering Vol. 1, No. 1, 2015, pp. 26-32. http://www.publicscienceframework.org/journal/ijlse

Sarker, S. and Wells J.D., (2003). "Understanding Mobile Handheld Device Use and Adoption". Communications of the ACM, 46 (12) pp. 35-40

Sheng, H., Fui-Hoon Nah F., Siau K., (2005). "Strategic Implications of Mobile Technology: A Case Study Using Value-Focused Thinking”. The Journal of Strategic Information Systems, 14, (3), pp 269-290.

Thompson, H., and Garbacz, C. (2008). "Broadband Impacts on State GDP: Direct and Indirect Impacts". Paper presented at the International Telecommunications Society 17th Biennial Conference, Canada.

United Nations (2014). Online Statistics. From: https://data.un.org/CountryProfile. aspx?crName (accessed Dec 2014).

United Nations Educational, Scientific and Cultural Organization (UNESCO) (2014). Online Statistics. From: http://www.uis.unesco.org/DataCentre/Pages/country-pro file. aspx ?code $=440 \&$ SPSLanguage $=\mathrm{EN}$ (accessed Dec 2014).

Varian, H.R., Farrell, J., and Shapiro, C., (2004) "Economics of Information Technology: An Introduction". Cambridge University Press, New York.

World Bank Global ICT Department. (2014). "The Little Data Book on Information and Communication Technology 2014" From: https://openknowledge.worldbank. org/bitstream/handle/10986/22554/9781464805585.pdf

World Bank (2012). "ICT for Greater Development Impact". Retrieved from: http://siteresources.worldbank.org/EXTINFORMATIONANDCOMMUNICATI ONANDTECHNOLOGIES/Resources/WBG_ICT_Strategy-2012.pdf.

World Bank (2014). "World Development Indicators". Retrieved from: http://data. worldbank.org/indicator. WorldBank, Washington, DC. 
